\title{
DAMPAK KESEJAHTERAAN GURU PAI MI/SD TERHADAP KOMPETENSI PROFESIONAL DI KECAMATAN WEDUNG KABUPATEN DEMAK
}

\author{
M. Fahmi Maulana \\ Sekolah Tinggi Agama Islam Nahdhatul Ulama Pacitan \\ Email:maulanafahmi2@gmail.com
}

\begin{abstract}
Abstrak:
Seorang guru tetap dituntut untuk professional dalam bertugas walaupun profesi guru sifatnya nirlaba. Guru berhak memperoleh penghasilan dan jaminan kesejahteraan yang pantas sesuai dengan Undang-Undang Sisdiknas No 20 Tahun 2003. Hasil observasi dilapangan menunjukan sekolah atau madrasah swasta maupun negeri hanya memberikan gaji bagi guru honorer kurang lebih sebesar Rp. 300.000,00 - Rp. 800.000,00 setiap bulannya, dapat dipastikan seorang guru harus memutar otak agar kebutuhannya terpenuhi. Tujuan penelitian adalah untuk mengetahui tingkat kesejateraan dan kompetensi professional guru PAI MI/SD di Kecamatan Wedung Kabupaten Demak, serta mengetahui ada dampak atau tidak antara tingkat kesejahteraan dengan kompetensi professional. Dalam penelitian ini peneliti menggunakan pendekatan kuantitatif dengan analisis regresi sederhana. Hasil penelitian menunjukkan: (1) Tingkat kesejahteraan guru berada pada kategori sedang; (2) Tingkat kompetensi profesional guru berada pada kategori sedang (3) Berdasarkan analisis uji regresi linear sederhana diperoleh hasil nilai t-hitung $<$ t-tabel yaitu $1,727<2,101$ dengan signifikansi 5\% bahwa tingkat kesejahteraan guru tidak memberikan pengaruh yang signifikan terhadap tingkat kompetensi profesional guru. (4) Tingkat kompetensi profesional guru dipengaruhi oleh faktor-faktor lain (motivasi, komitmen, supervisi, workshop, KKG, Micro teaching, monitoring dan evaluasi).
\end{abstract}

Kata Kunci: Kesejahteraan, Kompetensi Profesional, Guru PAI MI/SD

\section{PENDAHULUAN}

$1 \begin{aligned} & \text { enjadi sejahtera adalah salah satu tujuan hidup manusia, tetapi dalam } \\ & \text { perjalanannya, kehidupan yang di jalani manusia tidak selamanya dalam } \\ & \text { kondisi sejahtera. Seperti halnya seorang guru, guru tetap dituntut untuk }\end{aligned}$ professional dalam bertugas walaupun seorang guru merupakan sebuah profesi yang sifatnya nirlaba. Walapun bersifat nirlaba, guru berhak memperoleh penghasilan dan jaminan kesejahteraan yang pantas dan memadai sesuai dengan Undang-Undang Sistem Pendidikan No 20 Tahun 2003. Yang menjadi pertanyaan disini adalah apabila guru sudah bekerja secara professional apakah jaminan akan 
kesejahteraan yang diberikan pemerintah saat ini sudah membuat guru hidup sejahtera atau sebaliknya. Guru memiliki peranan yang signifikan dalam lembaga pendidikan Islam (Umar; jamilah, 2017). Di satu sisi status guru merupakan profesi yang artinya guru harus menguasai ilmu pengetahuan di bidangnya dan terampil dalam menyampaikan materi kepada peserta didik. Guru juga harus memantau perkembangan siswanya serta dapat menyelesaikan masalah yang dihadapi siswa. Namun kebanyakan orang tua cenderung menyerahkan anak sepenuhnya kepada pihak sekolah. Mereka lupa bahwa pendidikan bagi anak juga merupakan tanggung jawab orang tua. Seakan orang tua tidak tahu bahwa tugas guru tidak hanya mengajar, tetapi juga harus menyelesaikan berbagai administrasi yang tidak sedikit di luar jam pembelajaran. Apabila seluruh kewajiban itu harus dipenuhi guru berarti guru harus bekerja selama 24 jam.

Status guru dalam budaya dan masyarakat Indonesia, secara formal masih menempati tempat yang terhormat, namun secara material status atau profesi guru mengalami kemerosotan yang menghawatirkan. Hampir diseluruh Indonesia penghargaan material terhadap guru sangat minim, bahkan sebagian besar guru berada di bawah garis kemiskinan (Tilaar, 2002).

Beberapa dekade ini kesejahteraan guru menjadi topik pembicaraan utama, berkaitan dengan tuntutan dalam bidang pendidikan yang semakin tinggi juga diikuti dengan tuntutan kesejahteraan guru yang gencar disuarakan oleh para pendidik di seluruh Indonesia. Realitasnya sekolah atau madrasah swasta maupun negeri hanya memberikan gaji perbulannya bagi guru honorer kurang lebih sebesar Rp. 300.000,00 - Rp. 800.000,00 setiap bulannya, dapat dipastikan seorang guru dalam memenuhi kebutuhannya harus memutar otak agar kebutuhannya terpenuhi. Seperti guru PAI yang meminjam kepada koperasi dan sebagai jaminannya adalah gaji setiap bulan dipotong sebagai angsuran, sehingga gajinya tiap bulan tinggal sedikit. Ada juga guru honorer di Kecamatan Wedung Kabupaten Demak yang sudah mengajar di Madrasah Ibtidaiyah kurang lebih 15 tahun dilihat dari kehidupannya sangat sederhana sekali, dilihat dari luar, rumah bagian samping, dindingnya belum diplester atau masih terlihat batu bata dan jika dilihat dari segi sosialnya beliau juga kurang bahkan tidak mengaktualisasikan dirinya di masyarakat.

Namun ada juga guru honorer yang mengajar kurang lebih 10 tahun tetapi berkehidupan mewah, beliau memiliki penghasilan lain atau sampingan. Jika dilihat dari bentuk rumahnya, beliau memiliki rumah dua lantai dan jika dilihat dari sosialnya beliau juga mengaktualisasikan dirinya didalam organisasi masyarakat. Kondisi yang demikian, akan memotivasi guru untuk sepenuhnya menuangkan waktunya dalam menjalankan tugas atau pekerjaannya. Terutama guru PAI di SD/MI yang mengajarkan moral dan agama pada peserta didik. Dengan terpenuhinya kepuasan guru, guru tidak akan setengah hati dalam 
menjalankan tugas. Tingginya tingkat kesejahteraan guru merupakan faktor penentu yang amat penting bagi kinerja guru dalam menjalankan tugasnya. Menurut Dedi Supriadi, berdasarkan hasil dari studi internasional mengenai mutu pendidikan di berbagai negara dilaporkan bahwa negara-negara yang memberikan perhatian khusus pada gaji dan peningkatan kesejahteraan guru lebih baik mutu pendidikannya (Supriadi, 2002).

Dari uraian permasalahan diatas peneliti ingin mengkaji lebih mendalam lagi tentang kesejahteraan guru PAI SD/MI di Kabupaten Demak, selain alasan diatas peneliti memilih Kabupaten Demak karena Kabupaten Demak merupakan salah satu kabupaten dengan angka kemiskinan yang masih tergolong tinggi, lebih tepatnya di kecamatan Wedung, kecamatan wedung merupakan kecamatan yang berada di pesisir. Masyarakat pesisir identik dengan pertumbuhan ekonomi yang masih lemah atau tidak sejahtera. Maka dari itu penelitian ingin sangat penting untuk menggambarkan bagaimana profil Guru PAI MI/SD di Kabupaten Demak agar nantinya menjadi pijakan bagi pembuat kebijakan sosial khususnya di bidang kesejahteraan guru.

Penelitian Ade Cahyana pada tahun 2010 berkaitan tentang Pengembangan Kompetensi Profesional Guru, memaparkan hasil bahwa sertifikasi merupakan salah satu upaya pemerintah dalam meratakan dan meningkatkan kesejahteraan guru. Disamping itu, sertifikasi guru juga dinilai sebagai salah satu kebijakan reformasi pendidikan untuk meningkatkan profesionalisme guru yang merupakan kegiatan terintegrasi dengan kegiatan pembelajaran di sekolah, untuk meningkatkan kualitas mengajar mereka sebagai guru, dan memberi peluang bagi mereka dalam meningkatkan kemampuan profesional sekaligus menambah kredit akumulatif mereka untuk kepentingan sertifikasi (Cahyana: 2010).

Selaras dengan hasil penelitian sebelumnya, penelitian atas nama Muhammad Syaifullah, 2013, tentang kesejahteraan guru bahasa arab di Kabupaten Kulon Progo dengan hasil (1) guru Bahasa Arab di Kabupaten Kulon Progo memiliki tingkat kesejahteraan yang tinggi dinjau dari BPS Kabupaten Kulon Progo; (2) ditinjau dari indikator BKKBN ada 3 guru yang masuk dalam kategori Keluarga Guru sejahtera III Plus dan pra sejahtera 3 orang dengan alasan bukan dari segi ekonomi melainkan belum nikah dan tidak berani KB; (3) $83 \%$ dari responden menyatakan bahwa ada pengaruh kesejahteraan guru terhadap kinerja guru di sekolah (Syaifullah, 2013).

Percival M. Symonds dan Robert T. Ford juga telah melakukan penelitian berkaitan dengan kesejahteraan guru. Melalui jurnalnya yang berjudul Welfare of the Teacher, Percival dan Robert memaparkan bahwa kesejahteran guru dipengaruhi oleh beberapa faktor, yaitu: (1) keamanan ekonomi dengan dijamin oleh gaji yang memadai, hak untuk cuti, dan kenaikan jabatan; (2) peningkatan kecakapan profesional melalui berbagai pelatihan; (3) keamanan pribadi yang 


\section{eL-Muhbib}

Jurnal Pemikiran dan Penelitian Pendidikan Dasar

ISSN 2614-1051 Volume 5 Nomor 2 Desember 2021

meliputi kebebasan akademik, sosial dan hubungan interpersonal yang demokratis, dan (4) kondisi kerja yang nyaman meliputi jam kerja, beban murid, karakter tugas, ketersediaan bahan ajar, dan karakter lingkungan fisik guru. Dari studi pustaka yang sudah ada, menurut peniliti masih perlu dikaji lebih mendalam mengenai tingkat kesejahteraan yang kemungkinan berdampak pada kompetensi profesional guru (Robert and Ford, 1952).

\section{TINJAUAN TEORITIS}

\section{Kesejahteraan}

Kesejahteraan berasal dari kata "sejahtera". Sejahtera dalam Bahasa Sanskerta "catera" berarti payung. Dalam konteks ini, kesejahteraan yang terkandung dalam arti "catera" adalah orang yang sejahtera yaitu orang yang dalam hidupnya bebas dari kemiskinan, kebodohan, ketakutan, atau kekhawatiran sehingga hidupnya aman dan tentram baik lahir maupun batin (Fahrudin, 2014). Kesejahteraan dapat dipenuhi melalu bekerja, karena kerja merupakan konsep dasar dari manusia sosio ekonomi. Melalui kerja manusia mengubah dunia eksternalnya dan melalui kerja pula manusia dapat menunjukkan eksistesi dirinya. Dengan bekerja manusia dapat memenuhi kebutuhannya.

Menurut Abraham Maslow kebutuhan manusia dibagi menjadi 5 (lima) hierarki (Santoso, 2010), yaitu sebagai berikut:

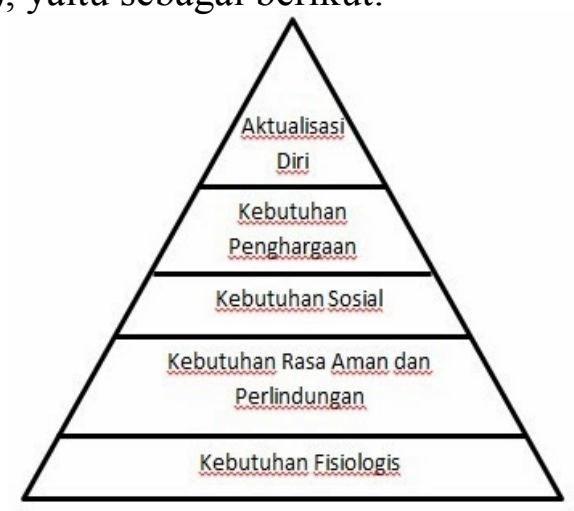

1. Kebutuhan fisiologis

Kebutuhan fisiologis merupakan kebutuhan yang sangat primer dan harus dipenuhi, karena kebutuhan fisiologis merupakan kebutuhan untuk mempertahankan hidup. Apabila kebutuhan ini tidak terpenuhi maka kebutuhan-kebutuhan yang lain akan terganggu bahkan tidak akan terpenuhi (Asmadi, 2008). Kebutuhan fisiologis meliputi kebutuhan akan oksigen, makan, minum, istirahat dan lain sebagainya.

Kebutuhan fisiologis yanng berarti kebutuhan primer jika dikaitkan dengan pekerjaan maka didalamnya termasuk kebutuhan akan upah atau gaji, liburan, istirahat dan lain sebagainya (Iskandar; 2016). Setelah kebutuhan 
fisiologisnya terpenuhi maka orang akan mencari atau memenuhi kebutuhan lainnya yang lebih tinggi.

2. Kebutuhan akan rasa aman

Kebutuhan akan rasa aman adalah kebutuhan yang berhubungan dengan neurotik dan kecemasan. Apabila kebutuhan ini tidak terpenuhi maka orang tersebut akan merasa takut dan cemas. Orang yang seperti itu pasti akan menghindari hal-hal yang bersifat asing dan tidak diinginkannya.

Kebutuhan akan keamanan pada organisasi atau pekerjaan terlihat pada keinginan untuk mengamankan imbalan atau gaji, ketepatan waktu menerima upah, kondisi kerja yang aman, asuransi, tunjangan pensiun dan lain-lain.

3. Kebutuhan sosial

Setelah kebutuhan fisiologis dan kebutuhan akan rasa aman terpenuhi maka, seseorang akan beralih atau menggapai kebutuhan yang selanjutnya, yakni kebutuhan akan kawan, cinta dan perasaan diterima (Iskandar; 2016). Kebutuhan ini merupakan suatu dorongan seseorang untuk menjalin hubungan yang bermakna atau hubungan emosional dengan orang lain.

Manusia sebagai makhluk sosial akan senang apabila mereka disenangi, dan dorongan ini akan menekan seseorang sehingga orang tersebut berupaya semaksimal mungkin untuk mendapatkan pemenuhan kebutuhan akan sosial, cinta dan perasaan diterima. Kebutuhan ini muncul pada waktu mereka bekerja sama dengan rekan-rekan sekerja, dan turut membantu kelompokkelompok maupun individu-individu dalam bekerja serta kegiatan-kegiatan yag diadakan perusahaan mereka bekerja (Iskandar: 2016).

Seorang guru harus memiliki jiwa sosial, jiwa mencintai dan dicintai yang besar bagi anak didiknya. Kebutuhan akan mencintai dan dicintai akan sangat berpengaruh pada kepribadian seseorang terutama pada anak. Karena anak yang tumbuh dengan cinta kasih sayang maka di dalam diri anak akan tumbuh rasa kasih sayang. Begitu pula sebaliknya, anak yang tumbuh dengan kekerasan maka didalam diri anak akan tumbuh perilaku yang keras dan akan melakukan kekerasan ketika dewasa. Sebab, sebagian besar perilaku anak merupakan proses peniruan baik orang tuanya, guru, teman, maupun orang dewasa yang ada disekitarnya (Asmadi, 2008). Contoh kebutuhan sosial adalah: berkeluarga, diakui sebagai anggota, diajak berpartisipasi dalam organisasi, dan lain-lain

4. Kebutuhan akan harga diri

Kebutuhan selanjutnya adalah kebutuhan akan harga diri. Apabila kebutuhan terhadap sosial, mencintai dan dicintai telah terpenuhi maka seseorang akan mencapai tingkat kebutuhan akan harga diri. Terpenuhinya kebutuhan harga diri tampak dari sikap penghargaan diri (Asmadi, 2008). 
kebutuhan ini berhubungan dengan citra positif dengan orang lain seperti menerima perhatian, pengakuan, dipercaya dan apresiasi dari orang lain.

5. Kebutuhan aktualisasi diri

Kebutuhan yang paling tingi adalah kebutuhan aktualisasi diri. Aktualisasi diri merupakan kemampuan seseorang untuk mengatur diri sendiri sehingga bebas dari berbagai tekanan baik yang berasal dari diri sendiri maupun dari luar diri sendiri. Kebutuhan ini diantaranya adalah kebutuhan untuk mengembangkan potensi yang ada di dalam dirinya secara menyeluruh, meningkatkan kemampuan yang ada pada diri sendiri.

Kebutuhan yang menyangkut aktualisasi diri contohnya adalah pengembangan karir, mengembangkan kreativitas, mendapatkan pelatihan untuk mendapatkan tugas yang menantang.

Berkaitan dengan teori hierarki kebutuhan Abraham Maslow tersebut, sesuai dengan UU Nomor 14 tahun 2005 Pasal 14 ayat (1) huruf a yang berbunyi "guru berhak memperoleh penghasilan di atas kebutuhan hidup minimum dan jaminan kesejahteraan sosial", yang ditegaskan ulang dalam pasal 15 yaitu "Penghasilan di atas kebutuhan hidup minimum sebagaimana dimaksud dalam Pasal 14 ayat (1) huruf a meliputi gaji pokok, tunjangan yang melekat pada gaji, serta penghasilan lain berupa tunjangan profesi, tunjangan fungsional, tunjangan khusus, dan maslahat tambahan yang terkait dengan tugasnya sebagai guru yang ditetapkan dengan prinsip penghargaan atas dasar prestasi”, maka kesejahteraan guru adalah hal pokok yang perlu diperhatikan

\section{Kompetensi Profesional}

Menurut W. Robert Houston dalam Roestiyah, kompetensi dirumuskan sebagai suatu tugas yang memadai, atau pemilikan pengetahuan, keterampilan dan kemampuan yang dituntut oleh jabatan seseorang (Janawi, 2012). Dalam dunia pendidikan kompetensi yang melekat pada guru bersifat sangat komplek.

Berdasarkan Peraturan Pemerintah No.19 tahun 2005, guru sebagai tenaga pendidik harus memiliki empat jenis kompetensi, yakni: pertama, kompetensi kepribadian, berkenaan dengan kemampuan personal yang mencerminkan kepribadian yang mantap, stabil, dewasa, arif dan berwibawa, menjadi teladan bagi peserta didik dan berakhlak mulia. Kedua, kompetensi sosial, berkenaan dengan kemampuan guru sebagai bagian dari masyarakat untuk berkomunikasi dan bergaul secara efektif dengan peserta didik, sesama guru, tenaga kependidikan, orang tua/wali peserta didik dan masyarakat sekitar. Ketiga, kompetensi pedagogik, berkenaan dengan kemampuan memberikan pemahaman peserta didik dan pengelola pembelajaran yang mendidik dan dialogis. Secara 
substantif, kompetensi ini mencakup pelaksanaan pembelajaran, evaluasi hasil belajar, dan pengembangan peserta didik untuk mengaktualisasikan berbagai potensi yang dimilikinya. Keempat, kompetensi profesional merupakan kemampuan yang berkenaan dengan penguasaan materi pembelajaran bidang studi secara luas dan mendalam yang memungkinkannya membimbing peserta didik memenuhi standar kompetensi yang ditetapkan dalam Standar Nasional Pendidikan.

Di bidang pendidikan, kompetensi profesional guru merupakan satu pilar penting yang haru dikembangkan untuk menjamin kualitas pendidikan. Raka Joni dalam Wahyudi memaparkan bahwa kemampuan profesional guru terus-menerus diupayakan agar berkembang sesuai kebutuhan lingkungan dan pertumbuhan jabatan profesi (Wahyudi, 2010).

Kompetensi profesional mencakup sub kompetensi sebagai berikut: (1) menguasai substansi keilmuan yang terkait dengan bidang studi, yaitu memahami materi ajar yang ada di dalam kurikulum sekolah, memahami struktur, konsep dan metode keilmuan yang menaungi atau koheren dengan materi ajar, memahami hubungan konsep antar mata pelajaran terkait, dan menerapkan konsep-konsep keilmuan dalam kehidupan sehari-hari; (2) menguasai langkah-langkah penelitian dan kajian kritis untuk menambah wawasan dan memperdalam pengetahuan / materi bidang studi (Wahyudi, 2010).

Kompetensi profesional berhubungan dengan penguasaan kemampuan teoritik dan praktik. Secara rinci, kemampuan profesional dapat dijabar sebagai berikut (Janawi, 2012):

1. Menguasai materi, struktur, konsep dan pola pikir keilmuan yang sesuai dan mendukung bidang keahlian / bidang studi yang diampu;

2. Memanfaatkan teknologi informasi dan komunikasi (TIK) untuk meningkatkan kualitas pembelajaran sesuai bidang studi yang diampu;

3. Mengusai filosofi metodologi, teknis, dan praksis penelitian dan pengajaran serta pengembangan ilmu yang sesuai dan mendukung bidang keahliannya;

4. Mengembangkan diri dan kinerja profesionalitasnya dengan melakukan tindakan reflektif dan penggunaan TIK;

5. Meningkatkan kinerja dan komitmen dalam pelaksanaan pembelajaran dan pengabdian kepada masyarakat.

Selain hal tersebut di atas, bentuk kompetensi profesional guru sebagai pengajar adalah keterampilan dalam mengajak dan membangkitkan peserta didik untuk berpikir kritis. Kemampuan tersebut harus didukung oleh kemampuan guru dalam menggunakan media ajar. Daniel dalam Janawi menunjukkan bahwa peranan guru sebagai motivator penting mengharuskan guru dapat merangsang dan memberikan dorongan serta reinforcement untuk mendinamisasikan potensi, 
menumbuhkan aktivitas dan kreativitas peserta didik sehingga terjadi dinamika dalam proses belajar mengajar (Janawi; 2012).

\section{METODE PENELITIAN}

Berdasarkan permasalahan yang diangkat oleh peneliti, maka penelitian ini menggunakan pendekatan kuantitatif. Jenis penelitian yang dimaksudkan adalah penelitian cause and effect. Penelitian cause and effect adalah penelitian yang mengungkap hubungan sebab akibat, bila X maka Y (Sugiyono, 2007). Penelitian ini dilakukan oleh peneliti bertujuan untuk menguji pengaruh tingkat kesejahteraan guru terhadap tingkat kompetensi profesional.

Dalam konteks penelitian ini, populasi yang dijadikan objek penelitian adalah Guru PAI MI/SD se-KecamatanWedung, Kabupaten Demak sejumlah 156 guru. Karena tidak semua data dan informasi yang akan diproses dan tidak semua orang atau benda akan diteliti melainkan cukup dengan menggunakan sampel yang mewakilinya. Sampel yang peneliti gunakan yaitu purposive sampling. Purposive sampling adalah salah satu teknik pengambilan sampel yang dilakukan secara sengaja, karena ada pertimbangan secara khusus.

Sampel yang dijadikan objek dalam penelitian ini terdiri atas MI Darussalam II Jetak Kecamatan Wedung Kabupaten Demak, MIN Jungpasir Kecamatan Wedung Kabupaten Demak, SDN Bungo I Kecamatan Wedung Kabupaten Demak, dan SD Islam Terpadu Ribhul Ulum di Kecamatan Wedung, Kabupaten Demak.

Teknik pengumpulan data yang digunakan peneliti adalah menggunakan angket untuk mengetahui tingkat kesejahteraan guru dan tingkat kompetensi profesional guru. Peneliti juga menggunakan metode dokumentasi untuk mengetahui profil sekolah dan data sekolah. Angket yang digunakan sebagai alat pengumpulan data dalam penelitian ini akan terlebih dahulu dilakukan pengujian yang meliputi uji validitas dan reliabilitas

Penelitian ini menggunakan teknik analisis regresi linier sederhana, karena variabel yang terlibat dalam penelitian ini ada dua, yaitu tingkat kesejahteran guru sebagai variabel bebas dan dilambangkan dengan $\mathrm{X}$ serta tingkat kompetensi profesional guru sebagai variabel terikat dan dilambangkan dengan Y. Beberapa tahapan uji untuk analisis data adalah uji prasyarat, uji hipotesis dan uji anova.

\section{HASIL DAN PEMBAHASAN}

\section{Tingkat Kesejahteraan Guru}

Berdasarkan penghimpunan dan olah data, dapat peneliti gambarkan presentase tingkat kesejahteraaan guru PAI MI/SD se- Kecamatan Wedung Kabupaten Demak dalam diagram lingkaran, sebagi berikut: 


\begin{tabular}{|c|l|c|}
\hline NO & INTERVAL & KATEGORI \\
\hline 1 & $105-108$ & $\begin{array}{c}\text { Sangat } \\
\text { Tinggi }\end{array}$ \\
\hline 2 & $100-104$ & Tinggi \\
\hline 3 & $96-99$ & Sedang \\
\hline 4 & $92-95$ & Rendah \\
\hline 5 & $89-91$ & $\begin{array}{c}\text { Sangat } \\
\text { Rendah }\end{array}$ \\
\hline 6 & $85-88$ & \multirow{2}{*}{} \\
\cline { 1 - 2 }
\end{tabular}

Tabel 1 : Tabel Kategori Tingkat Kesejahteraan

\section{Diagram Tingkat Kesejahteraan Guru PAI MI/SD Se- Kecamatan Wedung Kabupaten Demak}

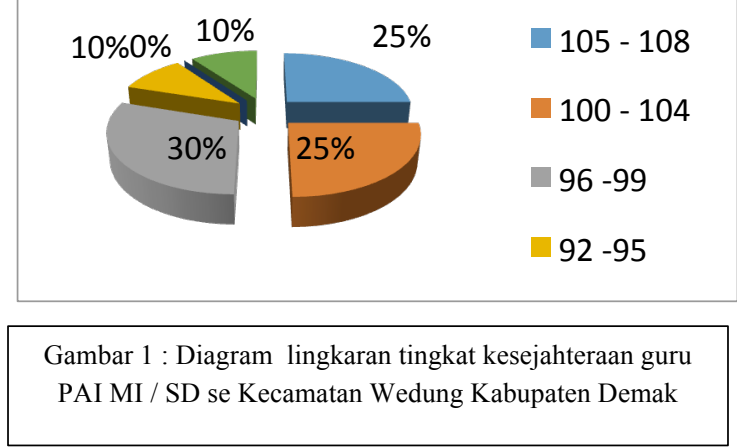

Berdasarkan diagram batang dan diagram lingkaran tersebut di atas, tergambar bahwa terdapat nilai yang terbanyak di interval 96-99 sebesar 35\%. Jika dibandingkan jumlah data keseluruhan, sebesar 55\% dari jumlah responden memiliki score kesejahteraan di bawah rerata ( kurang dari 99,5 ), yang artinya bahwa tingkat kesejahteraan guru PAI MI / SD di Kecamatan Wedung Kabupaten Demak termasuk dalam kategori sedang.

Fakta di lapangan menunjukkan bahwa sebanyak 10\% dari total responden menyatakan bahwa gaji yang diterima tidak dapat digunakan untuk memenuhi kebutuhan dasarnya, dan sebanyak 35\% menyatakan bahwa gaji yang diterimanya belum mencukupi kebutuhan pokok keluarganya secara tetap dan berkualitas. Tingginya tingkat kebutuhan dan gaya hidup, menyebabkan $85 \%$ dari responden menginginkan untuk mendapat tambahan gaji dari pekerjaan sampingan.

Sebanyak $80 \%$ dari responden menyatakan bahwa semua pemrosesan hak yang diterimakan kepada guru sudah dilakukan secara transparansi. Mereka juga mendapatkan jaminan keamanan dan kesehatan selama mereka bekerja di lembaga terkait. Tetapi, selama masa kerja ternyata sebanyak $20 \%$ responden tidak mendapatkan peningkatan gaji secara bertahap. Mereka mendapatkan gaji dari awal masuk hingga saat ini dengan nominal/besaran gaji yang sama (tetap). Selain hal tersebut, sebanyak 35\% dari total responden menyatakan bahwa selama melakukan pekerjaan di lembaga terkait mereka sering mendapatkan tekanan dari beberapa pihak (termasuk pihak pengelola maupun teman seprofesi).

Seluruh guru PAI MI/SD di Kecamatan Wedung Kabupaten Demak selalu mendapatkan kesempatan untuk bekerjasama dengan teman seprofesi (baik dalam satu lembaga sekolah itu sendiri ataupun dengan teman seprofesi dari lembaga lain), tetapi $40 \%$ dari mereka tidak mendapatkan kesempatan untuk mengikuti beberapa pelatihan dalam mengembangkan karir mereka. Sebagian besar dari guru-guru tersebut pernah menjadi koordinator disetiap kegiatan sekolah, namun 


\section{eL-Muhbib}

Jurnal Pemikiran dan Penelitian Pendidikan Dasar

ISSN 2614-1051 Volume 5 Nomor 2 Desember 2021

40\% diantara mereka tidak diperhatikan kesejahteraannya. 40\% dari mereka tidak mendapatkan uang kesejahteraan sebagai imbalan ataupun uang kegiatan untuk mengganti waktu mereka yang telah terpotong untuk mengikuti kegitan di lembaga tersebut.

Prestasi selama menunaikan pekerjaan seharusnya mendapatkan apresiasi yang sepatutnya dari lembaga pendidikan. Berdasarkan hasil penelitian yang didapatkan, terdapat fakta bahwa tidak semua lembaga sekolah memberikan apresiasi terhadap capaian prestasi kerja dari pekerjanya (guru). Sebanyak 35\% guru belum mendapatkan penghargaan yang sepadan dengan prestasi yang mereka raih. Aktualisasi diri merupakan tujuan utama dari suatu proses yang dilakukan. Dalam konteks penelitian ini, di beberapa lembaga sekolah ternyata masih terdapat manajemen personalia yang kurang memperhatikan jenjang karir guru. Sebanyak $10 \%$ dari total responden menyatakan bahwa di lembaga tempat mereka bekerja tidak terdapat jenjang karir yang jelas. Sebanyak $20 \%$ dari mereka juga menyatakan bahwa mereka tidak bisa menggunakan gaji yang mereka dapatkan untuk meningkatkan kualifikasi pendidikan mereka.

\section{Tingkat Profesionalisme Guru}

Berdasarkan hasil penghimpunan data dan analisis dapat peneliti gambarkan presentase tingkat kompetensi profesional guru PAI MI /SD seKecamatan Wedung Kabupaten Demak dalam diagram lingkaran, sebagi berikut:

\begin{tabular}{|c|c|c|}
\hline NO & INTERVAL & KATEGORI \\
\hline 1 & $124-128$ & $\begin{array}{c}\text { Sangat } \\
\text { Tinggi }\end{array}$ \\
\hline 2 & $119-123$ & Tinggi \\
\hline 3 & $114-118$ & Sedang \\
\hline 4 & $109-113$ & Rendah \\
\hline 5 & $104-108$ & $\begin{array}{c}\text { Sangat } \\
\text { Rendah }\end{array}$ \\
\hline
\end{tabular}

Tabel 2 : Tabel Kategori Tingkat Kompetensi Profesional Guru

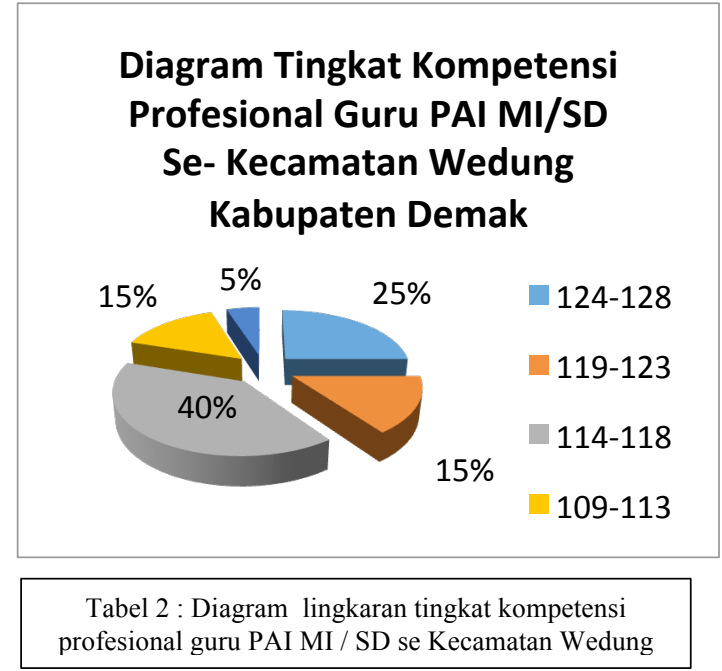

Berdasarkan diagram batang dan diagram lingkaran tersebut di atas, tergambar bahwa terdapat nilai yang terbanyak di interval $114-118$ sebesar $40 \%$. Jika dibandingkan jumlah data keseluruhan, sebesar $65 \%$ dari jumlah responden memiliki score kompetensi profesional di bawah rerata ( kurang dari 117,9), yang artinya bahwa tingkat kompetensi profesional guru PAI MI / SD di Kecamatan Wedung Kabupaten Demak termasuk dalam kategori sedang. 
Fakta yang terjadi di lapangan menunjukkan bahwa kompetensi profesional guru PAI MI / SD di Kecamatan Wedung Kabupaten Demak dalam ranah penguasan subtansi keilmuan yang terkait dengan bidang studi yaitu 95\% dari total responden (guru) selalu menguasai materi pelajaran terlebih dahulu sebelum memberikan pembelajaran kepada peserta didik, tetapi $25 \%$ diantara guru-guru tersebut belum memahami standar kompetensi dan kompetensi dasar dari mata pelajaran yang diampunya. Sebanyak 55\% dari total guru menyatakan bahwa mereka tidak selalu melihat isi buku ketika menjelaskan materi pembelajaran. Sebanyak $45 \%$ dari mereka hanya menggunakan buku pengangan saja dan tidak menggunakan buku- buku yang lain untuk menunjang materi pembelajaran. Sedangkan diakhir pembelajaran hanya terdapat $65 \%$ guru yang selalu mampu menyimpulkan materi pelajaran dengan baik.

Kompetensi profesional guru PAI MI/SD dalam pemanfaatan teknologi informasi dan komunikasi, serta sarana prasarana pembelajaran untuk meningkatkan kualitas pembelajaran sesuai dengan bidang studi yang diampu adalah sebagai berikut: sebanyak $20 \%$ dari guru-guru tersebut yang selalu menggunakan alat bantu belajar lain, sedangkan $80 \%$ yang lainnya tidak selalu menggukan alat bantu belajar lain yang meluputi slide, PPT dan sarana prasarana yang lain; sebanyak $85 \%$ dari jumlah guru dinyatakan tidak selalu menggunakan laboratorium untuk menunjang proses pembelajaran; dan sebanyak 50\% guru yang selalu menggunakan perpustakaan dalam pembelajaran. Untuk beberapa lembaga sekolah yang tidak memiliki perpustakaan, guru menyiasatinya dengan cara mengajak peserta didik ke perpustakaan daerah setempat.

Kompetensi profesional menekankan guru untuk menguasai filosofi metodologi, teknis, dan praktis penelitian serta pengajaran dan pengembangan ulmu yang sesuai dan mendukung bidang keahliannya. Berdasarkan hasil rekapitulasi angket didapatkan fakta bahwa sebanyak 75\% dari total guru selalu mengajar dengan menggunakan metode pembelajaran yang bervariasi (contohnya adalah metode ceramah, tanya jawab, demonstrasi, diskusi, dan lain-lain); 40\% dari guru tidak selalu mengulas dan menanyakan materi pelajaran yang sudah diajarkan pada pertemuan sebelumnya; dan 40\% diantaranya tidak terbiasa untuk memaparkan tujuan pembelajaran diawal proses pembelajaran berlangsung.

Selama menekuni profesi sebagai guru, guru harus selalu mengembangkan diri dan kinerja profesionalitasnya dengan melakukan tindakan reflektif dan pengusaan TIK. Berdasarkan fakta dilapangan sebanyak 90\% guru sering mengalami kesulitan dalam mengatur siswa didalam kelas, kerapihan tata ruang kelas, dan kesiapan peserta didik sebelum memulai pembelajaran. Sebanyak $80 \%$ dari jumlah guru menyatakan bahwa mereka tidak selalu merangcang, membuat, dan menggunakan alat peraga selama proses pembelajaran (alat peraga sederhana). Sebanyak $60 \%$ dari jumlah guru dinyatakan tidak selalu menggunakan 


\section{eL-Muhbib}

Jurnal Pemikiran dan Penelitian Pendidikan Dasar

ISSN 2614-1051 Volume 5 Nomor 2 Desember 2021

/memanfaatkan teknologi informasi dan komunikasi untuk mengembangan diri dan pengajaran. Disamping itu, hanya terdapat $25 \%$ dari jumlah guru yang selalu mengikuti berbagai pelatihan pengembangan diri, sedangkan yang $75 \%$ lainnya seirng dan kadang-kadang mengikuti.

Komitmen dalam pelaksanaan pembelajaran merupakan unsur penting dari kompetensi profesional seorang guru. Dalam konteks penelitian ini, terdapat sebanyak 5\% dari jumlah guru yang tidak selalu tertib selama proses pembelajaran, terdapat $35 \%$ guru yang tidak selalu mengawali dan mengakhiri pembelajaran dengan tepat waktu, terdapat $55 \%$ guru yang tidak selalu menyampaikan informasi tentang kemajuan, kesulitan, dan potensi pesera didik kepada wali murid baik dalam pertemuan fomal maupun tidak formal, sebanyak $75 \%$ guru yang tidak melakukan penelitian untuk mengembangkan karya inovasi dan mengikuti kegiatan ilmiah dalam ranah pendidikan serta aktif melaksanakan pengembangan keprofesian berkelanjutan, dan $45 \%$ diantara guru-gru tersebut tidak selalu aktif untuk membuat jurnal pembelajaran dan cataatan hasil penilaian proses pembelajaran yang menggambarkan kinerjanya.

\section{Dampak Kesejahteraan Guru terhadap Kompetensi Profesional Guru PAI MI/SD se- Kecamatan Wedung Kabupaten Demak}

Dalam pengolahan data penelitian ini, sebagai uji prasyarat untuk analisis regresi linier sederhana, peneliti menggunakan uji normalitas, uji homogenitas dan uji linieritas data, dengan hasil sebagai berikut:

Tests of Normality

\begin{tabular}{|l|r|r|r|r|r|r|}
\hline & \multicolumn{3}{|c|}{ Kolmogorov-Smirnov } & \multicolumn{3}{c|}{ Shapiro-Wilk } \\
\cline { 2 - 7 } & Statistic & \multicolumn{1}{c|}{ df } & \multicolumn{1}{c|}{ Sig. } & Statistic & \multicolumn{1}{c|}{ df } & \multicolumn{1}{c|}{ Sig. } \\
\hline profesional & .126 & 20 & $.200^{*}$ & .952 & 20 & .392 \\
Kesejahtera-an & .137 & 20 & $.200^{*}$ & .929 & 20 & .146 \\
\hline
\end{tabular}

a. Lilliefors Significance Correction

*. This is a lower bound of the true significance.

Tabel 3: Tabel uji normalitas data

Berdasarkan tabel hasil uji normalitas tersebut di atas (pada kolom Kolmogorov-Smirnov), tertera hasil bahwa nilai signifikansi untuk dependent variable (kompetensi professional) adalah 0,200 dan untuk independent variable (Kesejahteraan) sebesar 0,200. Karena nilai signifikansi untuk seluruh variabel dalam penelitian ini lebih besar dari signifikansi yang telah ditentukan sebelumnya, yaitu 0,05 (signifikansi dependent variable 0,200 >0,05 dan signifikansi independent variable 0,200 >0,05), maka dapat disimpulkan bahwa 


\section{eL-Muhbib}

Jurnal Pemikiran dan Penelitian Pendidikan Dasar

ISSN 2614-1051 Volume 5 Nomor 2 Desember 2021

data pada dependent variable (kompetensi professional) dan independent variable (kesejahteraan) tersebut adalah berdistribusi normal

\section{Test of Homogeneity of Variances}

Professional

\begin{tabular}{|c|c|c|c|}
\hline Levene Statistic & df1 & df 2 & Sig. \\
\hline .724 & 1 & 38 & .400 \\
\hline
\end{tabular}

Tabel 4 : Hasil Uji Homogenitas

Angka yang ditunjukkan pada kolom lavene statistic menunjukkan bahwa semakin kecil nilainya maka akan semakin besar homogenitasnya, sedangkan kolom $d f 1$ adalah menunjukkan jumlah kelompok data - 1 ( dalam penelitian ini $d f 1$ didapatkan dari 2-1=1), dan $d f 2$ adalah menunjukkan jumlah data - jumlah kelompok data (dalam penelitian ini $d f 2$ didapatkan dari $40-2=38$ ). Dari hasil olah data berdasarkan tabel tersebut di atas, dapat diketahui bahwa signifikansi yang dihasilkan sebesar 0,400. Karena signifikansi yang dihasilkan tersebut lebih besar dari signifikansi yang telah ditentukan sebelumnya yaitu sebesar 5\%, maka dapat disimpulkan bahwa data yang didapatakan dari penyebaran angket di lapangan tersebut mempunyai varian yang sama (data homogen).

ANOVA Table

\begin{tabular}{|c|c|c|c|c|c|c|c|}
\hline & & & $\begin{array}{l}\text { Sum of } \\
\text { Squares }\end{array}$ & df & $\begin{array}{c}\text { Mean } \\
\text { Square }\end{array}$ & $\mathrm{F}$ & Sig. \\
\hline \multirow{5}{*}{ 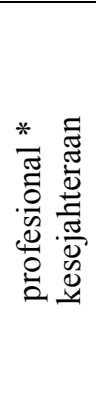 } & \multirow{3}{*}{$\begin{array}{l}\text { Between } \\
\text { Groups }\end{array}$} & (Combined) & 756.550 & 12 & 63.046 & 4.359 & .060 \\
\hline & & Linearity & 100.249 & 1 & 100.249 & 6.931 & .037 \\
\hline & & $\begin{array}{l}\text { Deviation } \\
\text { from } \\
\text { Linearity }\end{array}$ & 656.301 & 11 & 59.664 & 4.125 & .057 \\
\hline & \multicolumn{2}{|c|}{ Within Groups } & 101.250 & 7 & 14.464 & & \\
\hline & \multicolumn{2}{|l|}{ Total } & 857.800 & 19 & & & \\
\hline
\end{tabular}

Tabel 5: Uji Linearitas

Terdapat beberapa baris kolom hasil output ANOVA table. Ada dua hasil yang bisa kita lihat yaitu pada kolom F Linearity dan F Deviation from linearity. F Linearity menunjukkan sejauh mana variabel dependen diprediksi berbanding persis di garis lurus. Sedangkan F deviation from linearity menunjukkan tingkat / besarnya kasus devian dalam linieritas data.

Pada tabel tersebut di atas, dapat peneliti uraikan bahwa nilai F Linearity adalah sebesar 6,931 dengan probabilitas 0,037. Data tersebut menunjukkan bahwa F Linearity-nya berada pada rentang signifikansi yaitu sebesar 6,931 dengan probabilitasnya $<$ signifikansi yang telah ditentukan oleh peneliti yaitu $\mathrm{p}<0,05(\mathrm{~F}=6,931 ; \mathrm{p}<0,05)$. Sedangkan $\mathrm{F}$ deviation from linearity menunjukkan nilai $F$ nya sebesar 4,125 dengan probabilitas 0,057 . Data tersebut menunjukan 


\section{eL-Muhbib}

Jurnal Pemikiran dan Penelitian Pendidikan Dasar

ISSN 2614-1051 Volume 5 Nomor 2 Desember 2021

bahwa nilai $\mathrm{F}$ deviation from linearity berada pada rentang data yang tidak signifikan, yaitu sebesar 4,125 dengan ptobabilitasnya $>$ signifikansi yang telah ditentukan oleh peneliti sebesar $0,05(\mathrm{~F}=4,125 ; \mathrm{P}>0,05)$. Jadi, hasil pengujian linearitas data menggunakan uji ANOVA tersebut menunjukkan bahwa data -data yang diolah memiliki asumsi linearitas yang cukup kuat karena $\mathrm{F}$ Linearity berada pada rentang signifikansi $(F=6,931 ; p<0,05)$ dan $F$ deviation from linearity tidak berada pada rentang signifikansi $(\mathrm{F}=4,125 ; \mathrm{P}>0,05)$.

\begin{tabular}{|l|c|r|r|r|}
\hline \multicolumn{4}{|c|}{ Model Summary $^{\mathrm{b}}$} \\
\hline 1 & $\mathrm{R}$ & R Square & Adjusted R Square & Std. Error of the Estimate \\
\hline & $.342^{\mathrm{a}}$ & .117 & .068 & 6.487 \\
\hline
\end{tabular}

a. Predictors: (Constant), Kesejahteraan

b. Dependent Variable: Profesional

Tabel 6: Output I (Uji Regresi Linear Sederhana)

Berdasarkan output pada tabel diatas menjelaskan tentang besarnya nilai korelasi/hubungan yang dilambangkan dengan (R), yaitu sebesar 0,342. Sedangkan pada kolom R Square menjelaskan besarnya persentase (\%) pengaruh variabel Independent $(\mathrm{X})$ yaitu tingkat kesejahteraan Guru PAI MI/SD seKecamatan Wedung Kabupaten Demak terhadap variabel Dependent (Y) yaitu tingkat kompetensi profesional Guru PAI MI/SD se- Kecamatan Wedung Kabupaten Demak yang disebut dengan koefisien determinasi. Dari Tabel diperoleh nilai koefisien determinasi $\left(\mathrm{R}^{2}\right)$ sebesar 0,117 artinya bahwa pengaruh variabel independen (tingkat kesejahteraan Guru PAI MI/SD se- Kecamatan Wedung Kabupaten Demak) terhadap variable dependen (tingkat kompetensi profesional Guru PAI MI/SD se- Kecamatan Wedung Kabupaten Demak) adalah sebesar $14 \%$, sedangkan sisanya dipengaruhi oleh variabel lain di luar penelitian (di luar faktor kesejahteraan).

Kolom selanjutnya pada judul kolom Standard Error of the Estimate memperlihatkan tingkat keakuratan model regresi yang digunakan. Pada kolom tersebut tertera hasil penghitungan sebesar 6,487. Hasil / nilai tersebut semakin menjauhi angka nol, yang artinya model yang terbetuk tidaklah akurat

\begin{tabular}{|c|c|c|c|c|c|c|}
\hline \multicolumn{7}{|c|}{ ANOVA $^{b}$} \\
\hline \multicolumn{2}{|c|}{ Model } & $\begin{array}{l}\text { Sum of } \\
\text { Squares }\end{array}$ & df & Mean Square & $\mathrm{F}$ & Sig. \\
\hline 1 & Regression & 100.249 & 1 & 100.249 & 2.382 & $.140^{\mathrm{a}}$ \\
\hline & Residual & 757.551 & 18 & 42.086 & & \\
\hline & Total & 857.800 & 19 & & & \\
\hline
\end{tabular}




\begin{tabular}{|c|c|c|c|c|c|c|}
\hline \multicolumn{7}{|c|}{ ANOVA $^{b}$} \\
\hline \multicolumn{2}{|c|}{ Model } & $\begin{array}{l}\text { Sum of } \\
\text { Squares }\end{array}$ & $d f$ & Mean Square & $\mathrm{F}$ & Sig. \\
\hline 1 & Regression & 100.249 & 1 & 100.249 & 2.382 & $.140^{\mathrm{a}}$ \\
\hline & Residual & 757.551 & 18 & 42.086 & & \\
\hline & Total & 857.800 & 19 & & & \\
\hline
\end{tabular}

a. Predictors: (Constant), Kesejahteraan

b. Dependent Variable: Profesional

Tabel 7: Output II (Uji Regresi Linear Sederhana)

Tabel ANOVA fungsinya adalah untuk menjelaskan apakah ada pengaruh yang signifikan antara pengaruh variabel independen (tingkat kesejahteraan Guru PAI MI/SD se- Kecamatan Wedung Kabupaten Demak) terhadap variable dependen (tingkat kompetensi profesional Guru PAI MI/SD se- Kecamatan Wedung Kabupaten Demak).

Berdasarkan tabel tersebut di atas, penulis uraikan bahwa pada tabel ANOVA tersebut tertera nilai signifikansinya sebesar 0,140. Sedangkan nilai signifikansi yang telah ditentukan oleh peneliti sebelumnya adalah sebesar 0,05. Jika dibandingkan, maka signifikansi hasil uji tabel ANOVA lebih besar dari pada signifikansi yang telah ditentukan, yaitu $0,140>0,05$. Artinya, variabel independen (tingkat kesejahteraan Guru PAI MI/SD se- Kecamatan Wedung Kabupaten Demak) tidak berpengaruh terhadap variabel dependen (tingkat kompetensi profesional Guru PAI MI/SD se- Kecamatan Wedung Kabupaten Demak), karena nilai probalitas berada di atas signifikansi 0,05 .

Hal serupa juga ditunjukkan oleh nilai F-hitung dalam tabel ANOVA tersebut. Nilai F-hitung yang tertera dalam tabel tersebut adalah sebesar 2,382. Sedangkan nilai F-tabelnya adalah sebesar 4,41. F tabel dihitung menggunakan nilai probabilitas sebesar $5 \%$ dengan df1=1 dan df2=18. Jika dibandingkan besaran nilai $\mathrm{F}$ hitung dan $\mathrm{F}$ tabel, maka didapatkan hasil bahwa nilai $\mathrm{F}$ hitung lebih kecil dari pada F tabel yaitu 2,382<4,41. Artinya bahwa variabel independen (tingkat kesejahteraan Guru PAI MI/SD se- Kecamatan Wedung Kabupaten Demak) tidak berpengaruh secara signifikan terhadap variabel dependen (tingkat kompetensi profesional Guru PAI MI/SD se- Kecamatan Wedung Kabupaten Demak), karena nilai $F$ hitungnya lebih rendah dari pada $F$ tabel. Sebelum melakukan analisis tabel Coefficients, terlebih dahulu peneliti telah menentukan hipotesis statistiknya, yaitu sebagai berikut: 


\section{eL-Muhbib}

Jurnal Pemikiran dan Penelitian Pendidikan Dasar

ISSN 2614-1051 Volume 5 Nomor 2 Desember 2021

Ho: Tidak ada pengaruh yang signifikan antara tingkat kesejahteraan guru terhadap tingkat kompetensi profesional guru.

Ha: Ada pengaruh yang signifikan antara tingkat kesejahteraan guru terhadap tingkat kompetensi profesional guru.

Dengan hasil output tabel Coefficients sebagai berikut:

\begin{tabular}{|c|c|c|c|c|c|c|}
\hline \multicolumn{7}{|c|}{ Coefficients $^{a}$} \\
\hline \multirow{2}{*}{\multicolumn{2}{|c|}{ Model }} & \multicolumn{2}{|c|}{$\begin{array}{l}\text { Unstandardized } \\
\text { Coefficients }\end{array}$} & \multirow{2}{*}{$\begin{array}{l}\text { Standardized } \\
\text { Coefficients } \\
\text { Beta }\end{array}$} & \multirow[b]{2}{*}{$\mathrm{t}$} & \multirow[b]{2}{*}{ Sig. } \\
\hline & & $B$ & Std. Error & & & \\
\hline 1 & (Constant) & 78.005 & 25.890 & & 3.013 & .007 \\
\hline & Kesejahteraan & & .260 & .342 & 1.543 & .140 \\
\hline
\end{tabular}

a. Dependent Variable: Profesional

Tabel 8 : Output III (Uji Regresi Linear Sederhana)

Berdasarkan tabel Coefficients tersebut, nilai signifikansi yang tertera adalah sebesar 0,140. Sedangkan nilai signifikansi yang telah ditentukan oleh peneliti adalah sebesar 0,05. Nilai signifikansi pada tabel lebih besar dari pada nilai signifikansi yang telah ditentukan oleh peneliti $(0,140>0,05)$, sehingga Ho diterima. Artinya bahwa dalam konteks penelitian ini, tingkat kesejahteraan guru tidak memberikan pengaruh yang signifikan terhadap tingkat kompetensi profesional guru MI / SD se- Kecamatan Wedung Kabupaten Demak, dikarenakan nilai signifikansi yang dihasilkan lebih besar dari pada 0,05 .

Selain hal tersebut di atas, analisis juga dapat didasarkan pada nilai thitung yang tertera dalam tabel Coefficients tersebut untuk dibandingkan dengan nilai t-tabel. Berdasarkan tabel Coefficients tersebut nilai t-hitung sebesar 1,543. Sedangkan t-tabel dari jumlah responden 20 orang dan dengan taraf signifikansi $5 \%$ didapatkan nilai $\mathrm{t}$ tabel sebesar 2,101. Dalam konteks pengolahan data penelitian ini, nilai t-hitung lebih kecil dari pada t-tabel yaitu 1,543<2,101. Artinya bahwa Ho diterima atau tingkat kesejahteraan guru tidak memberikan pengaruh yang signifikan terhadap tingkat kompetensi profesional guru MI / SD se- Kecamatan Wedung Kabupaten Demak.

Tingkat kompetensi profesional guru PAI MI/SD se-Kecamatan Wedung Kabupaten Demak dipengaruhi oleh faktor-faktor lain, yaitu faktor internal (meliputi motivasi dan komitmen guru) dan faktor eksternal (program-program kepala sekolah/kepala madrasah terkait). Beberapa program-program kepala sekolah/madrasah yang berkontribusi terhadap tingkat kompetensi profesional guru meliputi supervisi secara berkala dan berkelanjutan, workshop, KKG, Micro teaching, serta monitoring dan evaluasi. 


\section{SIMPULAN}

Kesejahteraan dan kompetensi profesional guru adalah hal-hal penting yang perlu diperhatikan dalam dunia pendidikan. Berdasarkan hasil penelitian yang telah dilakukan, diperoleh simpulan bahwa: 1) Tingkat kesejahteraan guru berada pada kategori sedang; (2) Tingkat kompetensi profesional guru berada pada kategori sedang (3) Berdasarkan analisis uji regresi linear sederhana diperoleh hasil nilai t-hitung $<$ t-tabel yaitu 1,727<2,101 dengan signifikansi 5\% bahwa tingkat kesejahteraan guru tidak memberikan pengaruh yang signifikan terhadap tingkat kompetensi profesional guru. (4) Tingkat kompetensi profesional guru dipengaruhi oleh faktor-faktor lain (motivasi, komitmen, supervisi, workshop, KKG, Micro teaching, monitoring dan evaluasi).

\section{DAFTAR PUSTAKA}

Asmadi. (2008). Teknik Prosedural Keperawatan: Konsep Dan Aplikasi Dasar Klien. Salemba Medika.

Astuti, E. T. (2019). Prinsip Manajemen Tenaga Kependidikan Perspektif AlQur'an. Jurnal Iqra': Kajian Ilmu Pendidikan, 4(1), 128-145. https://doi.org/10.25217/ji.v4i1.465

Cahyana, A. (2010). Pengembangan Kompetensi Profesional Guru dalam Menghadapi Sertifikasi. Jurnal Pendidikan Dan Kebudayaan, 16.

Fahrudin, A. (2014). Pengantar Kesejahteraan Sosial. Refika Aditama.

Griffin, E. (n.d.). A First Look at Communication Theory. Mc. Graw-Hill.

Hariandja, M. T. E. (2007). Manajemen Sumber Daya Manusia. PT. Gramedia Widiasarana Indonesia.

Iskandar. (2016). implementasi teori herarki kebutuhan Abraham Maslow terhadap peningkatan kerja pustakawan. Jurnal Khizanah Al-Hikmah, 4.

J.Moleong, L. (2011). Metodologi Penelitian Kualitatif. PT. Remaja Rosdakarya.

Janawi. (2012). kompetensi Guru Citra Guru Profesional. Alfabeta.

Pemprov Jawa Tengah. (2017). Kebijakan Pemerataan Ekonomi Dalam Rangka Menurunkan Kemiskinan, Disampaikan pada: Rembuk Nasional Dalam Rangkaian Kegiatan Derakan Indonesia Mandiri Dalam kerja Nyata Revolusi Mental Indonesia di Hotel Best Western Solo Baru. Pemprov Jawa Tengah. 
Prercival M. Symonds and Robert T. Ford. (1952). Welfare of the Teacher. Review of Educational Research, XXII.

Priyanto, D. (2009). Mandiri Belajar SPSS. PT. Buku Kita.

Riduwan. (2004). Metode dan Teknik Menyusun Tesis. Alfabeta.

S.Andis Sukri, dan N. (2016). Profesionalisme Guru Pascasertifikasi. Jurnal Equilibrium, $I V$.

Santosa, S. (2014). SPSS 22 from Essential to Expert Skill. PT Elex Media Komputindo.

Santoso, S. (2010). Teori-teori Psikologi Sosial. Refika Aditama.

Sugiyono. (2007). Metode Penelitian Bisnis. CV Alfabeta.

Suharsimi, A. (2010). Prosedur Penelitian Suatu Pendekatan Praktik. PT Rineka Cipta.

Sukmadinata, N. S. (2013). Metode Penelitian Pendidikan. PT. Remaja Rosdakarya.

Suparlan. (2005). Menjadi Guru Efektif. Hikayat.

Supriadi, D. (1999). Mengangkat Citra dan Martabat Guru. Adicita Karya Nusa.

Syaifullah, M. (2013). kesejahteraan guru PAI di Kabupaten Kulon Progo, Yogyakarta. UIN SUKA.

Tilaar, A. . (2002). Membenahi Pendidikan Nasional. Rineka Cipta.

Umar; Jamilah, Sri. (2017). Peranan Pendidik Dalam Pendidikan Islam (orang tua, guru dan tokoh masyarakat. El-Muhbib: Jurnal Pemikiran Dan Penelitian Pendidikan Dasar, 1(2), 16-27.

Uzer Usman, M. (2007). Menjadi Guru Profesional. Remaja Rosda Karya.

Wahyudi. (2010). Standar Kompetensi Profesional Guru. Jurnal Pendidikan Sosiologi Dan Humaniora, Vol. 1.

Zanthy, L. (2010). Statistika Dasar. Artikel Ilmiah.

Zuriyah, N. (2009). Metode Penelitian Sosial dan Pendidikan teori dan aplikasi. Bumi Aksara. 